\title{
The comparison of obesity and physical activity levels of private and public secondary school children
}

\author{
Gonul BABAYIGIT IREZ, Emine KAYMAZ, Ozcan SAYGIN
}

Mugla Sitki Kocman University, Faculty of Sport Sciences, Mugla, Turkey.

Address Correspondence to G. Babayigit Irez, e-mail: gbabayigit@yahoo.com

\begin{abstract}
This study was conducted to compare of obesity and physical activity level of secondary school children in private school and public schools. Total 697 students consisting of 342 girls and 355 boys participated voluntarily in this study. Physical Activity Questionnaire for children was used to determine physical activity levels and height-weight measurement was performed to determine body mass index. It was found that the overweight ratio was $\% 9.49$ of girls in public secondary schools while the ratio of overweight girls was $\% 18.40$ in private schools. The boys' over weight ratios were $\% 23.58$ in public schools while the ratio of overweight was \% 27.5 in private schools. Significant differences were found between BMI and weight parameters of private and public secondary schools. No difference was found in physical activity levels of private and public school student. Moreover, there was no correlation between physical activity levels and BMI variables of students in private and public school according to gender. The physical activity levels of secondary school children' should be increased.
\end{abstract}

Keywords: Children, Obesity, Physical Activity.

\section{INTRODUCTION}

Obesity is one of the biggest health problems. In Europe, $15 \%$ of men and $22 \%$ of women are obese. In the USA, 4415 adults were examined and it was determined that the prevalence of obesity increased from $22.9 \%$ in the last 10 -year period to $30 \%$ in the 2000s. In various studies conducted in our country, obesity prevalence was found to be $7-12 \%$ in men and $22-30 \%$ in women (12). In addition, the prevalence of obesity in childhood was found to be $1.1 \%$ and $16.0 \%$ and the frequency of being overweight was $7.5 \%$ to $17.8 \%$ (19). Studies have shown that obesity increases the risk of developing hypertension, type- 2 diabetes, and cancer (3). In addition to age, gender, socioeconomic factors, less physical activity, over-eating, genetic, metabolic, hormonal factors and psychological problems can cause obesity (2).

Nutrition during childhood and infancy is of great importance during periods of growth and development. As a result of inadequate and unbalanced nutrition in the early stages of the childhood, the growth and development problems may cause some health problems that will affect our entire life. Childhood obesity is caused by imbalance in long-term energy intake and energy expenditure.
Physical inactivity associated with cardiovascular disease risk and bone health is one of the most important elements of childhood obesity (15). Childhood obesity should be detected at an early age and physical activity should be increased for a healthy generation. In the prevention of childhood obesity, early diagnosis is very important both clinical and public health. A healthy lifestyle habits that the child can gain during his or her life are gained more easily in childhood than adult years (11).

It has been proven by scientific research that every person can get rid of excess weight with regular exercises. By doing regular and continuous exercises, all the health problems caused by excessive lubrication can get rid of all the functions and capacities of our body can be transformed into active people (7). In addition, physically active children are less inclined to the development of cardiovascular risk factors and have better physical fitness and motor skills (14). There are many researches that is about childhood obesity continues in adulthood $(7,17)$. In this study, it was aimed to compare the levels of physical activity and whether 
students in private schools and students in public schools are prone to obesity or not.

\section{MATERIALS \& METHODS}

\section{Participants}

A total of 697 boy and girl secondary school students aged between 11 and 14 years who were studying in the 5th, 6th and 8th grades were selected by the Simple Random Sampling method. All participants who had no health problems studying in the secondary schools in Mugla were participated as voluntarily to this study. To determine obesity and physical activity levels, measures were taken during the school hours by obtaining necessary permissions from Mugla Provincial National Education Directorate, school and families. In order to fill the questionnaires in a healthy way needed support was received from branch teachers.

\section{Measurement tools}

Body Mass Index: Body mass Index was determined by dividing the body weight to the square of height $\left(\mathrm{kg} / \mathrm{m}^{2}\right)(23,24)$. Obesity classification was performed by using values for overweight and obesity in children aged 2-18 years (4).

Physical Activity Questionnaire for Children: The physical activity levels of the students were evaluated by Physical Activity Questionnaire for Children [PAQ-C 4-8]) developed by Crocker et al.
(1997). Physical Activity Questionnaire for Children (PAQ-C), which is adapted to Turkish version, was used. This questionnaire is intended to remember the activities that have taken place in the last 7 days. It gives an idea about the general physical activity habits of the participants. The scale consists of 9 questions graded from 1-5. In the calculation of the physical activity scores of the participants, the average of all questions was taken and 5 points at the highest level of physical activity and 1 point at the lowest level of physical activity (21).

\section{Statistical Analysis}

SPSS 16 package program was used to analyze the data measurements. Standard deviation, arithmetic mean, frequency and percentage values of the obtained data were calculated. The Kolmogorov Simirnov normality test was used to determine whether the data had a normal distribution, and after the data were found to be in accordance with the parametric test conditions, independent t-test was applied to determine the differences between the genders and schools. Moreover, the relationship between physical activity level and body mass index (BMI) values of boy and girl secondary school students were tested with Pearson Correlation Analysis. If $\mathrm{p}$ value is less than 0.05 , the difference is considered significant.

\section{RESULTS}

Table 1. Obesity incidence of girl and boy students studying in public and private schools

\begin{tabular}{cccccccccc}
\hline \multirow{2}{*}{ School } & \multirow{2}{*}{ Gender } & $\mathrm{N}$ & \multicolumn{2}{c}{$\begin{array}{c}\text { Average and } \\
\text { below }\end{array}$} & \multicolumn{2}{c}{ Overweight } & \multicolumn{2}{c}{ Obese } \\
\cline { 3 - 10 } & & & $\mathrm{f}$ & $\%$ & $\mathrm{f}$ & $\%$ & $\mathrm{f}$ & $\%$ \\
\hline Public & Girl & 179 & 157 & 87.70 & 17 & 9.49 & 5 & 2.79 \\
\cline { 3 - 10 } Schools & Boy & 195 & 141 & 72.30 & 46 & 23.58 & 8 & 4.10 \\
\hline Private & Girl & 163 & 129 & 79.14 & 30 & 18.40 & 4 & 2.45 \\
Schools & Boy & 160 & 107 & 66.87 & 44 & 27.5 & 9 & 5.62 \\
\hline
\end{tabular}

The rate of girl students attending public schools was $87,70 \%$, overweight ratio was $9,49 \%$ and obese rate was $2,79 \%$ in girls while obese ratio was found $4,10 \%$ in boys. The ratio of girl students studying in

Table 2. Arithmetic mean (X). standard deviation (SS) and independent- $t$ test results of girl and boy students studying in public schools

\begin{tabular}{|c|c|c|c|c|}
\hline \multirow[b]{2}{*}{ Variables } & $\operatorname{Girls}(\mathrm{n}=179)$ & Boys & & \\
\hline & $\bar{X} \pm S S$ & $\bar{X} \pm \mathrm{SS}$ & $\mathrm{t}$ & $\mathrm{p}$ \\
\hline Height $(\mathrm{cm})$ & $156.67 \pm 9.57$ & $157.89 \pm 11.04$ & - & - \\
\hline Body Weight (kg) & $46.21 \pm 10.25$ & $49.63 \pm 13.42$ & -2.74 & $<0.05^{*}$ \\
\hline Total score of Physical activity level & $27.25 \pm 7.10$ & $28.19 \pm 7.49$ & -1.24 & 0.21 \\
\hline BMI $\left(\mathrm{kg} / \mathrm{m}^{2}\right)$ & $18.66 \pm 2.96$ & $19.63 \pm 3.68$ & -2.80 & $<0.05^{*}$ \\
\hline
\end{tabular}

private schools was 79,14\%, overweight was 18,40\%, obese 2,45 , boy students were $66,87 \%$, overweight $27,5 \%$ and obese rate was $5,62 \%$. 
Significant differences were found in body weight $(t=-2,74, p<0,05)$ and BMI $(t=-2,80, p<0,05)$ of girl and boy students in public schools $(\mathrm{p}<0.05)$.
No significant difference was found in other variable.

Table 3. Arithmetic mean (X). standard deviation (SS) and Independent- $t$ test results of girl and boy students studying in private schools

\begin{tabular}{|c|c|c|c|c|}
\hline & Girls (n=163) & Boys & & \\
\hline Variables & $\bar{X} \pm S S$ & $\bar{X} \pm S S$ & $\mathrm{t}$ & $\mathrm{P}$ \\
\hline Height $(\mathrm{cm})$ & $157.37 \pm 9.57$ & $161.15 \pm 11.92$ & - & - \\
\hline Body Weight $(\mathrm{kg})$ & $49.63 \pm 10.93$ & $53.99 \pm 14.99$ & -2.98 & $<0.01^{* *}$ \\
\hline Total score of Physical activity level & $27.68 \pm 7.83$ & $28.37 \pm 7.45$ & -0.80 & 0.42 \\
\hline $\mathrm{BMI}\left(\mathrm{kg} / \mathrm{m}^{2}\right)$ & $19,89 \pm 3,36$ & $20,51 \pm 4,04$ & $-1,48$ & 0,14 \\
\hline
\end{tabular}

$\mathrm{P}<0.01$

Significant differences were found in body public schools. No significant difference was found weight $(t=-2,98, p<0,01)$ of girl and boy students in in other variables.

Table 4. Arithmetic mean (X). standard deviation (SS) and Independent $t$ test results of the measurement variables of girl students studying in public and private schools.

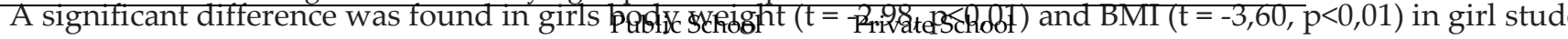

\begin{tabular}{lccccc} 
& \multicolumn{1}{c}{$(\mathrm{n}=179)$} & $(\mathrm{n}=163)$ & $\mathrm{X} \pm \mathrm{SS}$ & $\mathrm{t}$ & $\mathrm{p}$ \\
\cline { 2 - 6 } & Variables & $\bar{X} \pm \mathrm{SS}$ & $157.0 \pm 8.70$ & - & - \\
\hline Height $(\mathrm{cm})$ & $156.0 \pm 9.57$ & $49.63 \pm 10.93$ & -2.98 & $<0.01^{* *}$ \\
\hline Body Weight $(\mathrm{kg})$ & $46.21 \pm 10.25$ & $27.68 \pm 7.83$ & -0.53 & 0.60 \\
\hline Total score of Physical activity level & $27.25 \pm 7.10$ & $19.89 \pm 3.36$ & -3.60 & $<0.01^{* *}$ \\
\hline BMI $\left(\mathrm{kg} / \mathrm{m}^{2}\right)$ & $18.66 \pm 2.96$ & &
\end{tabular}

$\mathrm{P}<0.01$

Table 5. Arithmetic mean (X). standard deviation (SS) and Independent $t$ test results of boy students studying in public and private schools.

\begin{tabular}{|c|c|c|c|c|}
\hline & $\begin{array}{c}\text { Public School } \\
(\mathrm{n}=195)\end{array}$ & $\begin{array}{c}\text { Private School } \\
(\mathrm{n}=160)\end{array}$ & & \\
\hline Variables & $\bar{X} \pm S S$ & $\bar{X} \pm S S$ & $\mathrm{t}$ & $\mathrm{p}$ \\
\hline Height $(\mathrm{cm})$ & $157 \pm 13.42$ & $161 \pm 14.99$ & - & - \\
\hline Body Weight (kg) & $49.63 \pm 11.04$ & $53.99 \pm 11.92$ & -2.66 & $<0.01^{* *}$ \\
\hline Total score of Physical activity level & $28.11 \pm 7.50$ & $28.84 \pm 7.90$ & -0.73 & 0.46 \\
\hline $\mathrm{BMI}\left(\mathrm{kg} / \mathrm{m}^{2}\right)$ & $19.63 \pm 3.68$ & $20.51 \pm 4.04$ & -2.13 & $<0.05^{*}$ \\
\hline
\end{tabular}

$\mathrm{P}<0.05 . \mathrm{P}<0.01$

A significant difference was found between boy and girl students' body weight $(t=-2,66, p<0,01)$ and
BMI ( $\mathrm{t}=-2,13, \mathrm{p}<0,05)$. There was no significant difference in physical activity level.

Table 6. Correlation analysis of physical activity level and body mass index (BMI) values of boy and girl secondary school students studying at private and public schools

\begin{tabular}{cccc}
\hline Boys & & Private School & Public School \\
\hline & & BMI & BMI \\
\hline Physical Activity Level & $\mathrm{r}$ & -0.044 & -0.095 \\
\hline & $\mathrm{p}$ & 0.58 & 0.06 \\
\hline Girls & $\mathrm{N}$ & 160 & 195 \\
\hline Physical Activity Level & & Private School & Public School \\
\hline & $\mathrm{r}$ & $-0,092$ & $-0,045$ \\
\hline & $\mathrm{p}$ & 0,24 & 0,54 \\
\hline & $\mathrm{N}$ & 163 & 179 \\
\hline
\end{tabular}

No statistically significant relationship was found between the physical activity level and body mass index of the girl and boy students studying in public and private schools according to schools. 


\section{DISCUSSION}

The aim of this study was to compare obesity and physical activity levels of 11-14 years old girl and boy students in public and private secondary schools. Body composition changes continuously throughout the age of childhood and youth. These changes are caused by the increase in bone mineral density. changes in body water, resulting in the increase of body mass without lean body mass and the increase and decrease in fat mass. Gender differences between males and females occur with a difference in fat mass (13).

In this study, significant differences were found in the body weight and BMI values of girl and boy students studying in public schools $(\mathrm{p}<0,05)$. There was a significant difference between body weight of boy and girl students in private schools. In the study performed by Saygin and Mengutay (17) reported that the height, weight and BMI of the girls were higher than the boys, but no significant difference was found. Girls' height, body weight and BMI values increase significantly as age progresses. Although the BMI values of boys increased with age, the differences were not significant. In this study, there was a significant difference in body weight and BMI values of girl students studying in public schools and private schools $(p<0.05)$. A significant difference was found in the body weight and BMI values of boy students studying in public and private schools $(p<0,05)$. There was no significant difference in physical activity level. Ildız et al. (8) reported that body composition, physical activity level and physical self-perception of boys was found better than girls.

In a study performed by Kusgoz (9) found a significant difference in the age, weight, height and BMI rates of the students of the public school. In terms of weight, the values of girls and boys are slightly higher. The female students among the BMI scores were also higher than the male students. Among the genders of the students studying at the public school; there was a significant difference in age, weight and BMI. However, the values of women in all values were higher than that of men. There was a significant difference between the age and BMI values of the students in private schools. According to the research conducted by Sancak et al. (16), the BMI values of the students differ according to the types of schools. It was stated that the BMI values of the students attending private schools were higher than the students in the public school.
Simsek et al. (20) showed that most of the obese children did not do regular sports and this result caused a lack of physical activity in obesity development. Metinoglu et al. (10) found that $46,5 \%$ of the students who participated in the study were lower weight, $41,9 \%$ were normal, $10,4 \%$ were over weighted and $1,3 \%$ was obese. Moreover, $46 \%$ of the students were female and $64 \%$ were male. According to their research, 9,5\% of the women are overweight and $0,9 \%$ are obese while $11,2 \%$ are overweight and $1,5 \%$ are obese in males. No significant relationship was found between gender and BMI. In this study, the rate of female and male students attending public schools was $87,70 \%$, overweight ratio was $9,49 \%$ and obese rate was $2,79 \%$. The ratio of female and male students studying in private schools was $79,14 \%$, overweight was $18,40 \%$ and obese $2,45 \%$.

In a study conducted by Tekelioglu (22), 48.99\% of female students and $37,35 \%$ of male students have the appropriate body fat percentage, while $52,44 \%$ of female students and male students in private schools $37,61 \%$ have a normal body fat ratio. Other participants were found to have high body fat content. Alphan et al. (1) stated a study to compare public and private school children among obesity levels. Their study resulted as 12-13 age group of students in the public school of the students who have been determined as overweight at rate of $31,8 \%$ and private school students was found as overweight at rate of $21,1 \%$. In the study performed by Dagci and Saygin (5), male participants were determined to be $30 \%$ overweight and $6,3 \%$ obese. The female participants were $34,4 \%$ overweight and $26,5 \%$ obese. Demircioglu (6) was aimed to determine the physical activity levels of 39 women and 41 men between the ages of 11-13 years. For this aim, the numbers of steps were measured. The author concluded that women reached recommended number of steps during in the days of sports lecture. Boys are reported to have gone over the recommended number of steps in the weekdays and sports. In this study, no significant difference was found between the physical activity levels of female and male children. Saygin and Ceylan (18) found statistically significant difference was found in physical activity level of secondary school students, it was also found both high school student's body composition and physical activity levels according to gender $(\mathrm{p}<0.05)$. While the body mass index values of both male and female students 
tend to increase with age, physical activity level of both students tend to decrease with age.

\section{CONCLUSION \& RECOMMENDATIONS}

The results of physical activity and obesity levels were found to be similar among students REFERENCES

1. Alphan E, Keskin Y, Tatlı T. Özel okul ve devlet okulunda öğrenim gören adölesan dönemindeki çocukların beslenme alışkanlıklarının karşılaştırılması. Beslenme ve Diyet Dergisi, 2002;31(1): 9-17.

2. Atamtürk D. Alt sosyoekonomik düzeyde yer alan çocuklarda aşırı kiloluğun ve obezitenin yaygınlığı. Gaziantep Tip Dergisi, 2009;15(2):10-14.

3. Baltacı G. Çocuk ve Spor. Ankara: Klasmat Matbaacılık,2008.

4. Cole TJ, Marry CB, Katherine MF, William HD. Establishing a standard definition for child overweigh tand obesity worldwide: International Survey, BMJ, 2000; 320:1240-1243, USA.

5. Dagci G, Saygin O. Investigation of physical activity levels and body compositions of adolescent boys and girls. Studies on Ethno Medicine, 2015, 9(3), 385-390.

6. Demirci N. Okul dışı sportif etkinliklere katılan 11-13 yaşları arasındaki çocukların okul içi ve okul dışı adım sayılarının incelenmesi. Yayınlanmış Yüksek lisans Tezi, Hacettepe Üniversitesi Sağllk Bilimleri Enstitüsü Spor Bilimleri ve Teknolojisi Programı Yüksek Lisans Tezi, Ankara, 2017

7. Erkan N. Yaşam boyu spor. Ankara: Bağırgan Kitapevi,2000

8. Ildız M, Saygın Ö, Ceylan HI. Lise öğrencilerinin fiziksel benlik algisı, beden kompozisyonu ve fiziksel aktivite düzeyinin cinsiyete göre incelenmesi. SSTB International Refereed Academic Journal of Sports, Health \& Medical Sciences, 2015, 17, 116-129.

9. Kuşgöz A. Pansiyonlu ve normal devlet ilköğretim ile özel ilköğretim öğrencilerinin beslenme, fiziksel aktivite alışkanlıkları ve fiziksel uygunluklarının karşılaştırılması. Yayınlanmış Yüksek lisans Tezi. Muğla Üniversitesi Sosyal Bilimler Enstitüsü, Muğla, 2005

10. Metinoglu I, Pekol S, Metinoglu Y. Kastamonu'da 10-12 yaş grubu öğrencilerde obezite prevalansı ve etkileyen faktörler. Acıbadem Üniversitesi Sağlık Bilimleri Dergisi, 2012, 3(2), 117123.

11. Muratlı S. Çocuk ve spor. Nobel Yayıncılık, Ankara,2003

12. Orhan Y, Bozbora A. Obezite. İstanbul Medikal Yayıncllı, İstanbul, 2008

13. Özer K. Fiziksel Uygunluk. Nobel Yayıncilık, Ankara, 2006

14. Özgül B. Çocukluk Döneminde Fiziksel Aktivite. Türkiye Klinikleri Fizyoterapi ve Rehabilitasyon Dergisi, 2016, 2(1), 87-93. attending public schools and private schools. This may be due to the close proximity of the students' social economic levels and family education levels. Therefore, other studies can be done on students who are in different social economic situations.

15. Öztürk MA. Obez çocuklarda aerobik egzersizin sağlık ilişkili fiziksel uygunluk unsurlarina ve kan lipidlerine etkisi. Yayınlanmış Doktora Tezi, Muğla Üniversitesi Sosyal Bilimler Enstitüsü, 2009, Muğla, Türkiye.

16. Sancak R, Dündar C, Totan M, Çakır M, Sunter T, Küçüködük Ş. Ortaokul ve lise öğrencilerinde obezite prevelansı ve predispozan faktörler. O.M.Ü. Tip Dergisi, 1999, 16(1), 19-24.

17. Saygin Ö, Mengütay S. 10-12 Yaş Çocukların Fiziksel Uygunluklarının İncelenmesi. Spor ve Tip Dergisi, 2003, 11(5), 30-35.

18. Saygin, Ö, Ceylan H İ. Ortaokul ve lise öğrencilerinin beden kütle indeksi ile günlük adım sayısının yaşa ve cinsiyete göre karşılaştırılması. International Journal of Sport, Exercise $\mathcal{E}$ Training Sciences, 2017, 3(4), 142-152.

19. Sen M. Birinci basamakta çocuk ve adolesan obezitesi yönetimi. Jour Turk Fam Phy, 2016;07 (4): 85-93. Doi: 10.15511/tjtfp.16.00485

20. Simsek F, Ulukol B, Berberoğlu M, Gülnar S, Adıyaman P, Öcal G. Ankara'da bir ilköğretim okulu ve lisede obezite sıklığı. Ankara Üniversitesi Tıp Fakültesi Mecmuası, 2005, 58, 163-166.

21. Tanır H. İlköğretim 8. sinıf öğrencilerinde fiziksel aktivite düzeyi ve bazı antropometrik özelliklerin akademik başarı ile ilişkisi. Yayınlanmış Doktora Tezi, Kırıkkale Üniversitesi Sağlık Bilimler Enstitüsü, Kırıkkale, Türkiye, 2013

22. Tekelioglu A. Devlet okulu ve özel okulda okuyan 11-13 yaş grubu $k ı z$ ve erkek çocukların fiziksel uygunlukları. Yayınlanmış Doktora Tezi. Gazi Üniversitesi Sağlık Bilimler Enstitüsü, Ankara,1999

23. Zorba E, Ziyagil MA. Vücut kompozisyonu ve ölçüm metotları. Trabzon: Erek Ofset,1995

24. Zorba E., Saygin, Ö. Fiziksel aktivite ve fiziksel uygunluk. Ankara: İnceler Ofset Matbaacılık, 2009 